\title{
Phytoremediation of Boron Containing Synthetic Aqueous Solutions and Real Geothermal Water using Lemna minor
}

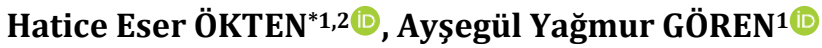 \\ 1İzmir Yüksek Teknoloji Enstitüsü, Mühendislik Fakültesi, Çevre Mühendisliği Bölümü, 35430, Urla, İzmir, \\ Türkiye, \\ ${ }^{2}$ İzmir Yüksek Teknoloji Enstitüsü, Çevre Geliştirme, Uygulama ve Araştırma Merkezi, 35430, Urla, İzmir, Turkey
}

(Alınış / Received: 22.09.2020, Kabul / Accepted: 16.03.2021, Online Yayınlanma / Published Online: 15.08.2021)

Keywords

Lemna minor L., Phytoremediation, Boron Removal,

Geothermal Water

\begin{abstract}
In this paper, phytoremediation performance of Lemna minor L. on boron (B) removal from synthetic solution and real geothermal brine was evaluated. Effects of B concentration, initial $\mathrm{pH}$, water height in cell, and initial humic acid concentration were investigated. The maximum removal efficiency was $96.7 \%$ with the experimental run with $\mathrm{B}$ concentration of $5 \mathrm{mg} \mathrm{L}^{-1}, \mathrm{pH} 8$, and $1.5 \mathrm{~cm}$ water depth. Increasing the $\mathrm{B}$ concentration from 5 to $30 \mathrm{mg} \mathrm{L}^{-1}$ resulted in a drastic decrease in removal efficiency to $36.6 \%$, due to the toxic effect of high boron content, which was clearly observed from deterioration of plant's color and structure. SEM, FTIR, and mass balance analyses revealed that the boron removal mechanism was mainly biosorption. Geothermal water experiments indicated L. minor's applicability with $59.5 \%$ removal efficiency, proving high potential in being used for post-treatment of geothermal waters with high boron content.
\end{abstract}

\section{Bor İçeren Sentetik Sulu Çözeltilerin ve Jeotermal Suların Lemna minor Kullanılarak Bitkisel Arıtım Tekniği ile Islahı}

\section{Anahtar Kelimeler}

Lemna minor L., Bitki ıslahı, Bor Giderimi, Jeotermal Su

\begin{abstract}
Özet: Bu çalışma kapsamında bor içeren sentetik çözeltilerin ve jeotermal suların Lemna minor L. bitkisi kullanılarak ıslahı çalışılmıştır. Çalışmada başlangıç bor konsantrasyonu, $\mathrm{pH}$, arıtım hücresindeki su yüksekliği ve başlangıç hümik asit konsantrasyonlarının giderim verimi üzerine etkisi incelenmiştir. $5 \mathrm{mg} \mathrm{L}-1$ başlangıç bor konsantrasyonu, pH 8 ve $1,5 \mathrm{~cm}$ su derinliğinde yürütülen deneysel çalışma ile maksimum bor giderim verimi \% 96,7 olarak bulunmuştur. Başlangıç bor konsantrasyonunun 5'den $30 \mathrm{mg} \mathrm{L}-1$ 'e yükseltilmesi ile bitkinin rengi ve yapısı yüksek bor içeriğinin bitki üzerindeki toksik etkisi nedeni ile bozulmuştur ve sonucunda giderim verimi $36,6 \%$ olarak bulunmuştur. SEM, FTIR ve kütle dengesi analizleri, bor giderim mekanizmasının esas olarak biyosorpsiyon olduğunu ortaya koymuştur. Ek olarak, jeotermal su arıtımı çalışmaları, L. minor'un 59,5\% bor giderim verimliliği ile uygulanabilirliğini göstermiștir ve yüksek bor içeriğine sahip jeotermal suların son arıtımı için çalışmanın yüksek potansiyeli olduğunu kanıtlamıştır.
\end{abstract}

\section{Introduction}

Water scarcity problem, which from a strict economical perspective explains in higher cost for clean water and wastewater treatment, poses a significant problem for developing and developed countries alike. World Health Organization (WHO) reported that 748 million people lack access to clean and adequate water resources, while at least 2 billion people use water sources that are contaminated. While roughly $50.0 \%$ of the World's inhabitants facing with water scarcity, one third of it have limited excess to energy services $[1,2]$. Therefore, availability and accessibility to safe and secure water resources are the key technological and scientific problems of global significance.

Utilization of geothermal waters for various domestic purposes dates back to ancient times as evidence shows Native Americans using it for cooking approximately 10,000 years ago. However, realization of geothermal resources' economic potential has

\footnotetext{
*ilgili yazar: haticeokten@iyte.edu.tr
} 
occurred much recently, starting with the implementation of the first geothermal electric power plant in Larderello, Italy in 1904 and leading to global power generation of $92 \mathrm{TWh}$ as of 2019. China, USA, Sweden, Turkey, and Japan have a largest geothermal energy use with a $55.0 \%$ of world use. Turkey has a significant amount of geothermal capacity with 31,500 MWh and almost $77.9 \%$ of this capacity is found in west Anatolia (Aydın-Germencik, Denizli-Kızıldere, Çanakkale-Tuzla and others) [3]. Apart from utilization for energy, geothermal water resources also serve as drinking, agricultural, industrial, and domestic water supplies, especially in arid regions [4]. Geothermal waters are characterized by diverse physicochemical parameters depending on their hydrogeothermal properties, characteristics of the rocks involved, the depth at which resources occur, and the source of water supply. Geothermal waters contain considerable amounts of anions, cations, and neutral species [5]. Evaluating the composition of geothermal waters, boron (B) content stands out as it is higher in comparison to boron concentrations generally found in sea water and brackish water. The main sources of boron are either natural such as leaching from boron containing rocks, borates and borosilicates containing soils, and volcanic activities or industrial such as manufacturing of detergents, cleaning products, semiconductor, borosilicate glass, cosmetics, fertilizers, flame retardants and dyestuff [6]. Boron is commonly found as boric acid $\left(\mathrm{H}_{3} \mathrm{BO}_{3}\right)$ and tetrahydroxoborate ions $\left(\mathrm{B}(\mathrm{OH})^{-}\right)$in geothermal waters and thermal springs. The pKa value of 9.25 marks the transition $\mathrm{pH}$ between $\mathrm{H}_{3} \mathrm{BO}_{3}$ and $\mathrm{B}(\mathrm{OH})_{4}$ species. Below pH 9.25, the dominant species in water is $\mathrm{H}_{3} \mathrm{BO}_{3}$ and above $\mathrm{pH} 9.25, \mathrm{~B}(\mathrm{OH})_{4}$ - becomes the dominant species $[7,8]$.

Due to high mineral content of geothermal waters, they shall be treated prior to any type of intended use apart from energy utilization. Boron content of these sources may pose significant risks to groundwater, surface water, aquatic life and vegetation [9] in the case of untreated discharges. Even though boron is an important nutrient for plants, it may be toxic at high concentrations for nearly all plants despite their wide range of tolerance. For instance, recommendation level to prevent boron related plant toxicity in irrigation water is lower than $0.5 \mathrm{mg} \mathrm{L}^{-1}$ for blackberry and lemon orchards; $1 \mathrm{mg} \mathrm{L}^{-1}$ for walnut, plum, pear, and apple; $2 \mathrm{mg} \mathrm{L}^{-1}$ for sunflower, potato, cotton, and tomato; $4 \mathrm{mg} \mathrm{L}^{-1}$ for asparagus, palm, bean, and onion $[7,10,11]$. Moreover, long term exposure to boron through ingestion may cause nausea, lethargy, diarrhea, vomiting, dermatitis, as well as intellectual and physical problems at children and risk of miscarriage in pregnancies $[12,13]$. Therefore, WHO recommended 2.4 and $1 \mathrm{mg} \mathrm{L}^{-1}$ as the limit values for boron in drinking water and irrigation water, respectively [14].

There are several treatment technologies for boron removal from aqueous solutions including coagulation, sedimentation, filtration, adsorption, ionexchange, electrocoagulation; membrane processes; bio-electrochemical systems [7, 15-17]. Despite achieving above $95 \%$ boron removal rates, membrane based desalination processes are need significant energy [17-19]. Reverse osmosis (RO) desalination is a widely-used process for bulk water production, consuming around $4 \mathrm{kWh} / \mathrm{m}^{3}$ energy corresponding to $0.35-0.50 \$ / \mathrm{m}^{3}$ in treatment costs [20].

Recently, interest in environmentally friendly, cheap, and effective treatment technologies have been increasing. Phytoremediation, being one of these treatment technologies, is used to remove, reduce, and immobilize contaminants from the aqueous solutions to enhance water quality as an environmentally friendly treatment option. Phytoremediation is based on the application of plant species to accumulate contaminants in aquatic environment. Several aquatic macrophytes, invasive plants, and floating plants have been studied for the removal of various contaminants in water and wastewater sources. Lemna gibba, Lemna minor, Chlorella sp., and S. polyrhiza species were used for the bioremediation and assessment of boron toxicity on plants [21-24]. Among these aquatic plants Lemna minor for phytoremediation process is advantageous due to its small size, simple structure, easy adaptation to diverse aquatic conditions, rapid grow rate, and high ability to accumulate contaminants from water sources [25-27]. However, the studies on boron removal using aquatic plants have been commonly carried out considering the boron accumulation and boron toxicity in plants while the studies about the effect of operational variations on boron accumulation, toxicity, and removal efficiency are inadequate; therefore, this study aims to fill these gaps.

The goal of this paper was to investigate the effect of operating parameters (initial $\mathrm{pH}$, initial boron concentration, initial natural organic matter concentration, effect of water height in cell) on boron removal efficiency of $L$. minor from aqueous solutions. Moreover, the boron removal from real geothermal brine was studied at optimized operating parameters. According to our research this is the first study about boron removal by Lemna minor with proposed targets.

\section{Material and Method}

\subsection{Solutions}

Boric acid $\left(\mathrm{H}_{3} \mathrm{BO}_{3}\right.$, Sigma Aldrich) solutions were prepared with $5,10,20$, and $30 \mathrm{mg} / \mathrm{L}$ of final $B$ concentrations, which were selected to represent the range that was generally found in geothermal water compositions $[5,16]$. The $\mathrm{pH}$ of prepared solutions was adjusted using $0.1 \mathrm{M} \mathrm{NaOH}$ and $0.1 \mathrm{M} \mathrm{HCl}$ solutions. Hoagland solution, a synthetic nutrient solution for Lemna minor, was prepared by dissolving $118 \mathrm{mg}$ of $\mathrm{Ca}\left(\mathrm{NO}_{3}\right)_{2} .4 \mathrm{H}_{2} \mathrm{O}, 0.008 \mathrm{mg} \mathrm{CuSO}_{4}, 0.004 \mathrm{mg}$ of $\mathrm{CoCl}_{2} .2 \mathrm{H}_{2} \mathrm{O}, 0.3 \mathrm{mg}$ of $\mathrm{FeSO}_{4} .7 \mathrm{H}_{2} \mathrm{O}, 0.3 \mathrm{mg}$ of $\mathrm{H}_{3} \mathrm{BO}_{3}$, 
$5 \mathrm{mg}$ of $\mathrm{KNO}_{3}, 0.68 \mathrm{mg}$ of $\mathrm{KH}_{2} \mathrm{PO}_{4}, 0.35 \mathrm{mg}$ of $\mathrm{K}_{2} \mathrm{SO}_{4}, 5$ $\mathrm{mg}$ of $\mathrm{MgSO}_{4} .7 \mathrm{H}_{2} \mathrm{O}, 0.15 \mathrm{mg}$ of $\mathrm{MnSO}_{4} .7 \mathrm{H}_{2} \mathrm{O}, 0.00128$ mg of $\left(\mathrm{NH}_{4}\right) 6 \mathrm{Mo}_{7} \mathrm{O}_{2} 4.4 \mathrm{H}_{2} \mathrm{O}, 0.005 \mathrm{mg}$ of $\mathrm{NiSO}_{4} .7 \mathrm{H}_{2} \mathrm{O}$, and $0.022 \mathrm{mg}$ of $\mathrm{ZnSO}_{4}$ in a liter of DI water [28]. Humic acid (HA, 50-60\%, Acros Organics) was used for simulation of natural organic matter.

\subsection{Characterization of real geothermal brine}

Geothermal brine was obtained from Balçova Geothermal Power Plant in İzmir, Turkey. The $\mathrm{pH}$ and electrical conductivity of geothermal water were 8.04 and $1770 \mu \mathrm{S} \mathrm{cm}-1$, respectively. Ionic content of geothermal brine was summarized in Table 1.

Table 1. Characterization of geothermal brine.

\begin{tabular}{cc}
\hline Parameters & Concentration $(\mathrm{mg} / \mathrm{L})$ \\
\hline $\mathrm{K}^{+}$ & $26.49 \pm 0.28$ \\
$\mathrm{NH}_{4}^{+}$ & $1.66 \pm 0.01$ \\
$\mathrm{Na}^{+}$ & $364.16 \pm 1.25$ \\
$\mathrm{Ca}^{2+}$ & $25.73 \pm 0.51$ \\
$\mathrm{Mg}^{2+}$ & $9.82 \pm 0.47$ \\
$\mathrm{NO}_{3}$ & $1.49 \pm 0.68$ \\
$\mathrm{Cl}^{-}$ & $171.16 \pm 2.93$ \\
$\mathrm{~F}^{-}$ & $7.41 \pm 1.24$ \\
$\mathrm{SO}_{4}^{2-}$ & $154.93 \pm 1.61$ \\
$\mathrm{Li}$ & $1.17 \pm 0.15$ \\
$\mathrm{As}$ & $0.17 \pm 0.02$ \\
$\mathrm{~B}$ & $10.48 \pm 1.63$ \\
\hline
\end{tabular}

\subsection{Lemna minor}

Aquatic plant of L. minor was purchased from an aquarium shop in İzmir, Turkey. Plants were washed with $2 \%$ hypochlorite (ClO-) to remove any undesired organisms and algae (Frederic et al., 2006). Plants were acclimatized in a $10 \mathrm{~L}$ plastic container with specified amount of synthetic nutrient solution under sunlight for one week prior to experiments.

\subsection{Experimental set-up}

Batch experiments that lasted 7 days were conducted to investigate boron removal. Experimental runs were conducted in glass cells with surface area of $12 \mathrm{~cm}^{2}$ (Fig. 1). $5 \mathrm{~g}$ of plant was transferred to cell which contained $50 \mathrm{~mL}$ of synthetically prepared boron solution. All experiments were conducted at $25{ }^{\circ} \mathrm{C}$, with a $16 \mathrm{~h}$ of light and $8 \mathrm{~h}$ of dark cycle. All experimental runs were carried out with three replicates and averaged data were used. Furthermore, control experiments for all experimental runs were conducted.
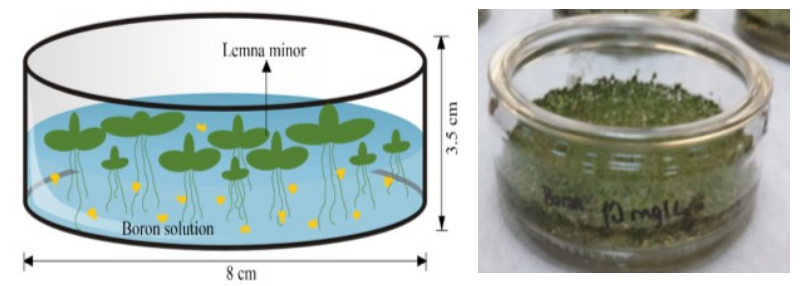

Figure 1. Experimental set-up of the Lemna minor containing glass cell.

\subsection{Analytical methods and calculations}

The $\mathrm{pH}$ was measured in boron containing solutions using a multimeter (Mettler Toledo, SevenCompact ${ }^{\mathrm{TM}}$ ). Water samples were filtered and analyzed for boron content using inductively coupled plasma optical emission spectrometer (ICP-OES, AGILENT 5110). Plant samples were also processed for boron content. Initially, boron exposed plant samples were dried at $60 \stackrel{\circ}{\circ}$ for $24 \mathrm{~h}$ in an oven. Then, $0.2 \mathrm{~g}$ of powdered biomass was mixed with $10 \mathrm{~mL} \mathrm{HNO}_{3}$, and $1 \mathrm{~mL} \mathrm{H}_{2} \mathrm{O}_{2}$ and was microwave-digested (MARS 6 ) at $200{ }^{\circ} \mathrm{C}$ for $30 \mathrm{~min}$. Then, digested samples were filtered and were analyzed for boron content by ICP-OES. Anions and cations in real geothermal water were analyzed by ion chromatography (IC, Dionex ICS-5000). Humic acid was measured by Shimadzu UV-2600 spectrophotometer at $\lambda_{\max }$ of $254 \mathrm{~nm}$. Standard deviations (SD) of all analyses were presented in supplementary material. Possible changes in surface morphology of dried L. minor before and after boron treatment experiments were investigated using Scanning Electron Microscopy (SEM, Quanta 250FEG). Energy dispersive X-ray spectrometry (EDX) was also performed for analyzing main elements present on raw and boron-exposed plant surfaces. Fourier Transform Infrared (FTIR) spectroscopy analyses were performed (Shimadzu FTIR 8400S) to compare functional groups before and after boron removal experiments. Boron removal efficiency (Re, \%) was calculated by the following equation:

$$
\operatorname{Re}(\%)=\frac{\left(C_{i, B}-C_{f, B}\right) 100}{C_{i, B}}
$$

$\mathrm{C}_{\mathrm{i}, \mathrm{B}}$ and $\mathrm{C}_{\mathrm{f}, \mathrm{B}}\left(\mathrm{mg} \mathrm{L}^{-1}\right)$ were initial and final boron concentrations in aqueous solution, respectively. Bioconcentration factor (BCF) of boron was calculated using the following equation (Marin and Onar, 2007; Zayed et al., 1998).

$$
B C F=C_{B, p l a n t} / C_{i, B}
$$

$\mathrm{C}_{\mathrm{B} \text {,plant }}$ was boron concentration $\left(\mathrm{mg} \mathrm{kg}^{-1}\right)$ in Lemna minor tissues. Mass balance of boron in treatment system was also calculated by the following equations:

$$
B_{\text {total }}=B_{\text {soluble }}+B_{\text {accumulated }}+B_{\text {insoluble }}
$$

where, $B_{\text {total }}$ t total boron in the treatment system (mg), Bsoluble: water soluble boron (mg), Baccumulated: accumulated boron by plant (mg), Binsoluble: insoluble forms of boron (mg).

$$
\begin{gathered}
B_{\text {total }}=C_{i, B} \times Q_{i} \\
B_{\text {soluble }}=C_{f, B} \times Q_{f} \\
B_{\text {accumulated }}=C_{B, \text { plant }} \times W_{d} \\
B_{\text {insoluble }}=B_{\text {total }}-B_{\text {soluble }}-B_{\text {accumulated }}
\end{gathered}
$$

where, $Q_{i}$ in initial water volume in $L$. minor containing cell (L), $Q_{f}$ : final water volume in cell (L), $W_{d}$ : dry weight of L. minor (g). 


\section{Results}

\subsection{Boron removal from synthetic solution}

Effects of initial pH, boron concentration, natural organic matter, and water height in cell on boron removal efficiency were investigated to elucidate the optimum operating parameters. Furthermore, B removal from real geothermal brine was investigated under optimum operating conditions.

\subsubsection{Effect of initial $\mathrm{pH}$}

The $\mathrm{pH}$ of the aqueous solutions have a significant impact on removal of boron in aqueous solutions and treatment performance of $L$. minor $[17,25]$. To examine the effect of $\mathrm{pH}(6,8$ and 10$)$, experimental runs were conducted using $20 \mathrm{mg} \mathrm{L}^{-1}$ of B solution, with $5 \mathrm{~g}$ of $L$. minor and operating time of 7 days. Specified $\mathrm{pH}$ values were selected to address the minimum and maximum $\mathrm{pH}$ values $L$. minor species can tolerate and to investigate boron speciation's effect on boron removal efficiency [29]. Boron removal efficiencies under different initial $\mathrm{pH}$ values were given in Fig. 2.

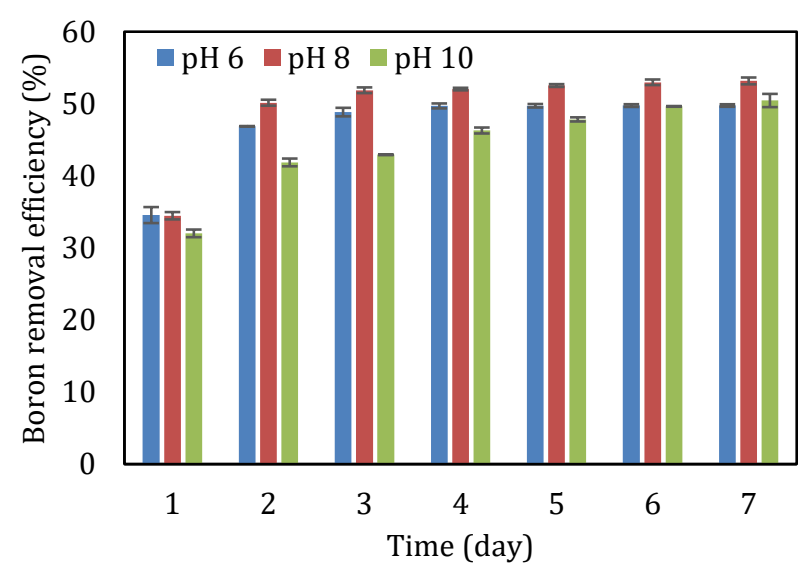

Figure 2. Boron removal efficiencies at different initial $\mathrm{pH}$ values.

Boron removal efficiencies were found to be $49.8 \%$, $53.2 \%$, and $50.5 \%$ for $\mathrm{pH}$ values of 6,8 , and 10 at the end of the operating time of 7 days, respectively (Fig. 2 ). The maximum $B$ contents were 1785,1815 , and $1838 \mathrm{mg} \mathrm{kg-1}$ at initial $\mathrm{pH}$ values of 6,8 , and 10, respectively. L. minor removed $\mathrm{B}$ with the highest removal efficiency of $53.2 \%$ and maximum $B$ uptake was $1815 \mathrm{mg} \mathrm{kg}^{-1}$ at $\mathrm{pH} 8$. Further increase in $\mathrm{pH}$ to 10 caused a small decrease in removal efficiency (50.5\%) and maximum uptake capacity (1838 $\mathrm{mg} \mathrm{kg}^{-1}$ ). Bioconcentration factors (BCF) were calculated to be $89.25,90.75$, and 91.9 for initial $\mathrm{pH}$ values of 6,8 , and 10 , respectively. There was no noticeable difference at specified $\mathrm{pH}$ values.

Researchers studied boron removal from contaminated waters using L. gibba and they found that the boron content in plant tissues were 900 and $1900 \mathrm{mg} \mathrm{kg}^{-1}$ for initial boron concentrations of 0.2 and $10 \mathrm{mg} \mathrm{L}^{-1}$, respectively at operating time of 12 days [30]. In a separate study, [22] investigated boron removal from mine effluent water using $L$. gibba. Boron content of plant was $2500 \mathrm{mg} \mathrm{kg}^{-1}$ at operating time of 7 days. These studies showed that our results were in good agreement with literature findings about boron accumulation in plant tissues.

Boron bioaccumulation in plant tissues may occur by diffusion and active transport of boron through plasmalemma, which is the permeability barrier of cell $[31,32]$. When L. minor is exposed to boron contaning solution, the boron concentration in tissuses is lower than that of solution. Therefore, the uptake of boron from solution to tissues occur as a result of rapid diffusion of $\mathrm{B}(\mathrm{OH})_{3}$ and slower active transport of $\mathrm{B}(\mathrm{OH})_{4}^{-}$. The diffusion of $\mathrm{B}(\mathrm{OH})_{3}$ will subsequently decrease until the boron concentration in L. minor tissues and boron containing solution equalize. After this stage, the boron uptake occurs only with the active transport of $\mathrm{B}(\mathrm{OH})_{4}$. Therefore, boron was probably taken up as boric acid by $L$. minor with diffusion mechanism during the operating time of 2 days. At the end of 2 days, the main uptake mechanism was active transport of $\mathrm{B}(\mathrm{OH})_{4}$. Accordingly, a significant increase in boron removal efficiencies was observed for 2 days due to rapid diffusion of $\mathrm{B}(\mathrm{OH})_{3}$ while the removal efficiencies were lower at the end of that period. Furthermore, the decrease of removal efficiency with the increase of initial $\mathrm{pH}$ from 8 to 10 can be explained with the $\mathrm{B}$ species in solution. Boron is found in $\mathrm{B}(\mathrm{OH})_{3}$ and $\mathrm{B}(\mathrm{OH})_{4}$ - forms at $\mathrm{pH} 8$ and at $\mathrm{pH}$ 10 , respectively [8]. Therefore, boron uptake was relatively higher at $\mathrm{pH} 8$ than $\mathrm{pH} 10$ due to the uptake of boron as $\mathrm{B}(\mathrm{OH})_{3}$ by rapid diffusion mechanism [33]. [21] studied boron removal by a Chlorella sp. and they found that the maximum $B$ removal was observed at $\mathrm{pH} 8$.

Results showed that there was no significant effect of initial $\mathrm{pH}$ of the solution on boron removal efficiency by $L$. minor. Since the maximum removal efficiency was observed at $\mathrm{pH} 8$ for boron removal using $L$. minor, experiments were conducted at $\mathrm{pH} 8$.

\subsubsection{Effect of boron concentration}

We studied effect of B concentrations of 5, 10, 20 and $30 \mathrm{mg} / \mathrm{L}$ at operating time of 7 days (Fig. 3). A rapid uptake of boron was observed for the $5 \mathrm{mg} \mathrm{L}^{-1}$ initial concentration in the first 4 days of operation. Later in the experiment uptake rate has slowed down, with an approximation to $100 \%$ removal efficiency. Experimental run with $10 \mathrm{mg} \mathrm{L}^{-1}$ showed a relatively rapid uptake of boron in the first 3 days. We also observed a delayed increase in uptake on the 7 th day of the experiment, which we assumed was due to an error in analysis. The removal efficiency was above 60 $\%$ at the end of the experiment. Doubling the concentration from 10 to $20 \mathrm{mg} \mathrm{L}-1$ resulted in a decrease in removal efficiency from $61.2 \%$ to $53.2 \%$. Boron uptake rate was higher in the first 2 days for the 
run with $20 \mathrm{mg} \mathrm{L}^{-1}$. The time needed to reach a plateau on boron removal efficiency graph has narrowed with increasing initial concentrations. However, boron removal efficiency kept increasing in the first 5 days of operation at $30 \mathrm{mg} \mathrm{B} / \mathrm{L}$. The maximum removal efficiency decreased significantly (36.6\%).

The decreases observed in boron uptake rates at different times for 5, 10, and $20 \mathrm{mg} \mathrm{L}^{-1}$ runs were most probably related to the sorption capacity of L. minor. The plant reached its limit much faster as the concentration was increased. On the other hand, the initial boron concentration of $30 \mathrm{mg} / \mathrm{L}$ was toxic for $L$. minor since we observed leaves turning yellow and rotting by the end of the experiment, which explained the poor removal efficiency. Despite being an essential nutrient for plant growth, boron overdose may cause toxicity [7, 11, 34]. Furthermore, ESEM results confirmed that the high concentration $(30 \mathrm{mg} / \mathrm{L})$ of Bexposed Lemna minor showed some toxic symptoms such as structural disorders in leaves and decrease in stomata. The steady increase in B uptake in the first 5 days of the experiment was probably due to adsorption rather than diffusion.

Our results were in good agreement with previous results observed by other researchers who studied boron toxicity on L. minor. Researchers reported that the aquatic macrophytes may suffer from necrosis, chlorosis, and may die when exposed to boron concentrations above $22 \mathrm{mg} \mathrm{L}^{-1}$. It was reported that high amounts of boron caused teratogenic effect and toxicity [35-37]. For instance, [38] reported that the initial boron concentration reaching up to $20 \mathrm{mg} \mathrm{L}-1$ was toxic for L. minor at 6 days. In a separate study, [22] studied L. gibba and they found that higher than $25 \mathrm{mg} \mathrm{B} \mathrm{L} \mathrm{L}^{-1}$ initial concentrations caused boron toxicity symptoms in 7 days. Boron content of L. minor samples increased gradually from $1271 \mathrm{mg} \mathrm{kg}^{-1}$ to $1904 \mathrm{mg} \mathrm{kg}^{-1}$ with the increase in initial boron concentration from 5 to $30 \mathrm{mg} \mathrm{L}^{-1}$, respectively. Our results were in agreement with the literature. For instance, [23] found that the boron content in L. gibba was $1296 \mathrm{mg} \mathrm{kg-1}$ for initial boron concentration of $5.58 \mathrm{mg} \mathrm{L}^{-1}$.

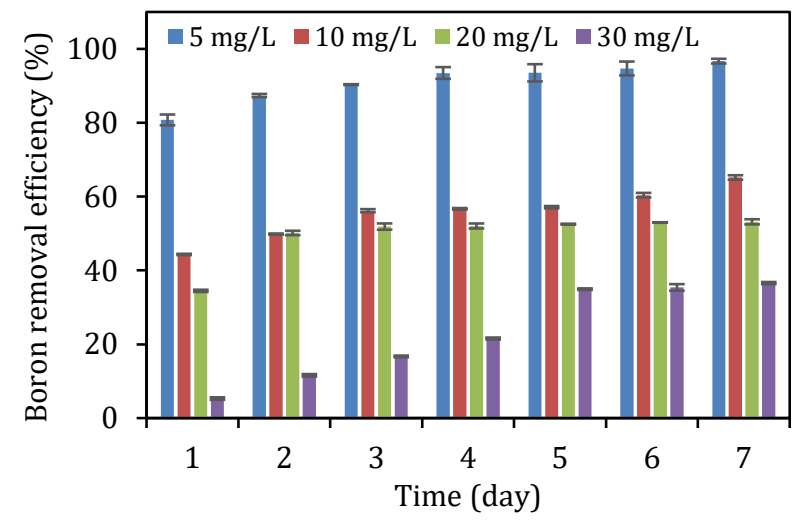

Figure 3. Removal efficiencies at different initial boron concentrations.
The BCFs were determined to evaluate the boron accumulation ability of the plant at different initial boron concentrations. As expected, the BCF values decreased with increasing initial boron concentrations and the maximum and minimum BCF values in Lemna minor were found as 254.12 and 63.48 at $B$ concentrations of 5 and $30 \mathrm{mg} \mathrm{L}^{-1}$, respectively. A similar result was observed by [30], they suggested that the decrease of BCF value at high boron concentrations was probably related to growth inhibition.

\subsubsection{Effect of humic acid}

Natural organic matter is a chemically active and critical component of water sources that occurs mainly by biological decay of plant and animal residues [39]. These compounds may interact with heavy metals, through which solubility and toxicity of heavy metals may be adversely affected [40]. Fig. 4 shows boron removal efficiencies at different humic acid (HA) concentrations $\left(0,1,2\right.$, and $\left.3 \mathrm{mg} \mathrm{L}^{-1}\right)$ at operating time of 7 days and $20 \mathrm{mg}-\mathrm{B} \mathrm{L}^{-1}$.

The maximum B removal efficiencies were observed as $33.1 \%, 38.1 \%$, and $30.9 \%$ for humic acid concentrations of 1,2 , and $3 \mathrm{mg} \mathrm{L}^{-1}$, respectively, at operating time of 1 day. Boron removal efficiencies decreased steadily in time with all investigated humic acid concentrations, which was probably due to the toxic effect caused by the interaction between boron and humic acid [41]. Boron and humic acid interaction may form complex/toxic compounds and these compounds cause decomposition of the plant structure. B concentration in solution was $22 \mathrm{mg} \mathrm{L}^{-1}$ at the end of all experimental runs, while the initial $B$ concentration was $20 \mathrm{mg} \mathrm{L}^{-1}$. Raw L. minor's B content was measured as $410 \mathrm{mg} \mathrm{kg}^{-1}$. Since all experiments were conducted using $5 \mathrm{~g}$ of L. minor and total boron content was calculated to be approximately $2.05 \mathrm{mg}$. These results revealed that the plant decomposed due to the toxic effect of humic acid/boron complexation and some portion of the boron inherently present in plant structure was released to the solution.

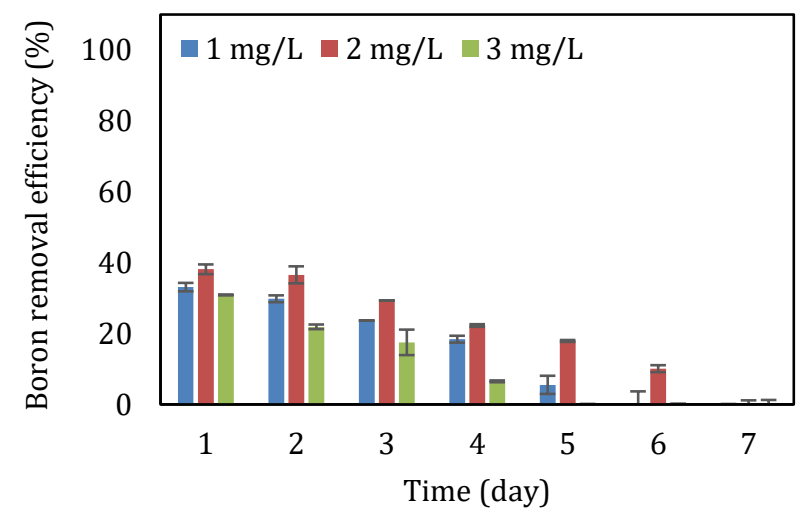

Figure 4. Boron removal efficiencies at different HA concentrations. 


\subsubsection{Effect of water height in cell}

As seen in Fig. 5, B removal decreased with the increase in water height in cell. Boron removal efficiencies were found as $53.1 \%, 35.9 \%$, and $32.7 \%$ at water heights of $1.5,3$, and $5 \mathrm{~cm}$, respectively. Boron removal efficiencies remained constant at the end of the operating time of 3 days for all water heights. In nature, L. minor can survive a pond depth of $0.5 \mathrm{~m}$ [42]. However, boron removal efficiency was negatively affected by increase in water height in cell. This can be explained by mixing rate of solution. Removal experiments were conducted without mixing, while in nature there is always a natural mixing of water in pond systems. We observed that in $1.5 \mathrm{~cm}$ depth, roots of L. minor could reach the bottom of the cell and therefore boron content in solution was fully accessible by the roots. However, in depths of $3 \mathrm{~cm}$ and $5 \mathrm{~cm}$, the roots were not able to reach the bottom of the cell, deeming some of the boron content inaccessible to the plants. Therefore, we concluded that boron removal efficiency of $L$. minor decreased due to insufficient mixing of solution.

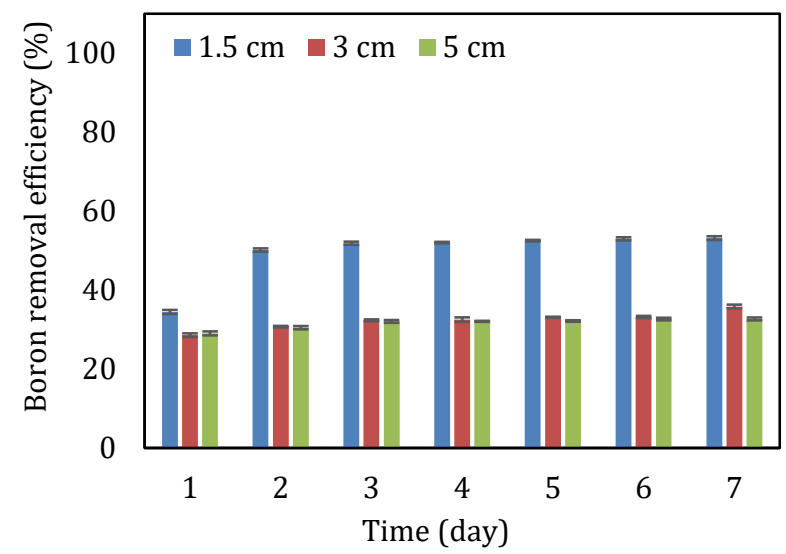

Figure 5. Boron removal efficiencies at different water heights in cell.

Boron contents and bioconcentration factors of $L$. minor at the end of the runs were $1815 \mathrm{mg} \mathrm{L}^{-1}$ and 90.75 for $1.5 \mathrm{~cm}$ depth; $1619 \mathrm{mg} \mathrm{L}^{-1}$ and 80.95 for $3 \mathrm{~cm}$ depth; $1132 \mathrm{mg} \mathrm{L}^{-1}$ and 56.60 for $5 \mathrm{~cm}$ depth. As expected, boron content and BCF values decreased with the increasing water height in cell.

\subsection{SEM and FTIR analysis}

Surface morphologies of raw and B-exposed L. minor were examined using SEM (Appendix A.). Results showed that the raw plant exhibited a heterogeneous structure with some cavities. In addition, the small fractures and deteriorations were observed probably resulting from grinding process. On the other hand, relatively small heterogeneous structure was observed on the surface of B-exposed L. minor probably due to agglomeration of boron on the leaf and roots of plant or inclusion of boron into the structure. Furthermore, elemental mapping using SEM revealed that the B-exposed plant consisted of relatively high amounts of $B$ when compared with the raw one. EDX results confirmed elemental mapping results, showing a change in ion content on raw and Bexposed plant surfaces (Appendix B.). Carbon content of raw plant decreased from the initial value of $53.9 \%$ to $48.6 \%$ at the end of the experiment (Appendix D.). Decreasing carbon content was estimated to be on account of organic matter depletion. On the other hand, there was no considerable change in oxygen content as both raw and B-exposed samples were examined under natural ventilation. Furthermore, $\mathrm{Na}$, $\mathrm{Mg}, \mathrm{K}$, and Ca elements were found on both surfaces. B content, which was not determined for raw sample, was found to be $1.97 \%$ on B-exposed plant surfaces. Accumulation of $\mathrm{B}$, most probably due to biosorption mechanism for L. minor, was observed [22].

In the FTIR spectra of B-exposed samples, the band at $711 \mathrm{~cm}^{-1}$ was attributed to the vibration (doublet) of the $\mathrm{B}-\mathrm{N}$ group that has medium intensity between 700 and $680 \mathrm{~cm}^{-1}$ (Appendix C.). Bands related to the B-H stretching observed at $2515 \mathrm{~cm}^{-1}$ which was in the suggested range of 2640-2350 $\mathrm{cm}^{-1}$. A strong "B $\cdots \mathrm{H} \cdots \mathrm{B}$ " bridge at $1535 \mathrm{~cm}^{-1}$ was also observed as given in the range of $1610-1525 \mathrm{~cm}^{-1}$. The methyl deformation vibrations of $\mathrm{B}-\mathrm{CH}_{3}$ were observed at 1421 and $1315 \mathrm{~cm}^{-1}$. According to literature, the vibrations of B-CH3 observe at $1460-1405 \mathrm{~cm}^{-1}$ and $1330-1280 \mathrm{~cm}^{-1}$, respectively [43]. The common peak at $3402.54 \mathrm{~cm}^{-1}$ corresponded to $\mathrm{N}-\mathrm{H}$ stretching related to the amino acids in plant structure while the peaks 2922.25 and $2850.88 \mathrm{~cm}^{-1}$ are for $\mathrm{C}-\mathrm{H}$ stretching due to the high load of lipids. The peaks of L. minor at $1319.35 \mathrm{~cm}^{-1}$ for $\mathrm{C}-\mathrm{O}$ stretching and $1658.84 \mathrm{~cm}^{-1}$ for $\mathrm{C}=0$ stretching corresponds to amide.

\subsection{Mass balance of boron in treatment system}

Boron removal using L. minor may occur through adsorption of boron on leaves and roots or through absorption. To establish the dominant form of B in the experiments, we conducted the mass balance analyses (Table 2).

At the first stage of the treatment process, soluble boron was the main fraction in the system. At the end of the operating time of 7 days, L. minor accumulated boron became the dominant form in the system. It could be observed that $31.7 \%$ to $93.6 \%$ of B was accumulated by plant, indicating that a considerable portion of boron was removed by biosorption. The maximum boron accumulation was found to be $93.6 \%$ at $5 \mathrm{mg}-\mathrm{B} \mathrm{L}^{-1}, \mathrm{pH}$ of 8 , and water height of $1.5 \mathrm{~cm}$. With the increase in initial $\mathrm{pH}$ from 8 to 10 , accumulated, water soluble, and insoluble boron concentrations were not significantly changed. Similar results were observed for the water height in cell. However, B content increased from 5 to $30 \mathrm{mg} \mathrm{B} \mathrm{L}^{-1}$, accumulated boron concentration decreased dramatically, while 
Table 2. Mass balance of boron at different operating conditions.

\begin{tabular}{|c|c|c|c|c|c|}
\hline \multicolumn{2}{|c|}{$\begin{array}{l}\text { Operating } \\
\text { parameter }\end{array}$} & $\begin{array}{l}\text { Total boron } \\
(\mathrm{mg})\end{array}$ & $\begin{array}{c}\text { Plant accumulated boron } \\
(\mathrm{mg})\end{array}$ & $\begin{array}{l}\text { Water soluble boron } \\
(\mathrm{mg})\end{array}$ & $\begin{array}{l}\text { Insoluble boron } \\
\text { (mg) }\end{array}$ \\
\hline \multirow{3}{*}{$\mathrm{pH}^{\mathrm{a}}$} & 6 & $1(100 \%)$ & $0.446 \pm 0.016(44.6 \%)$ & $0.261 \pm 0.054(26.1 \%)$ & $0.293 \pm 0.047(29.3 \%)$ \\
\hline & 8 & $1(100 \%)$ & $0.454 \pm 0.021(45.4 \%)$ & $0.234 \pm 0.013(23.4 \%)$ & $0.312 \pm 0.012(31.2 \%)$ \\
\hline & 10 & $1(100 \%)$ & $0.459 \pm 0.019(45.9 \%)$ & $0.248 \pm 0.028(24.8 \%)$ & $0.293 \pm 0.011(29.3 \%)$ \\
\hline \multirow{4}{*}{$\begin{array}{l}\text { Boron }^{b} \\
\left(\mathrm{mg} \mathrm{L}^{-1}\right)\end{array}$} & 5 & $0.25(100 \%)$ & $0.234 \pm 0.056(93.6 \%)$ & $0.004 \pm 0.014(1.6 \%)$ & $0.012 \pm 0.082(4.8 \%)$ \\
\hline & 10 & $0.5(100 \%)$ & $0.318 \pm 0.012(63.6 \%)$ & $0.087 \pm 0.026(17.4 \%)$ & $0.095 \pm 0.016(19.0 \%)$ \\
\hline & 20 & $1(100 \%)$ & $0.454 \pm 0.021(45.4 \%)$ & $0.234 \pm 0.013(23.4 \%)$ & $0.312 \pm 0.012(31.2 \%)$ \\
\hline & 30 & $1.5(100 \%)$ & $0.476 \pm 0.038(31.7 \%)$ & $0.476 \pm 0.095(31.7 \%)$ & $0.548 \pm 0.043(36.5 \%)$ \\
\hline \multirow{3}{*}{$\begin{array}{l}\text { Heightc } \\
(\mathrm{cm})\end{array}$} & 1.5 & $1(100 \%)$ & $0.454 \pm 0.125(45.5 \%)$ & $0.234 \pm 0.018(23.4 \%)$ & $0.312 \pm 0.024(31.2 \%)$ \\
\hline & 3 & $1(100 \%)$ & $0.405 \pm 0.056(40.5 \%)$ & $0.321 \pm 0.127(32.1 \%)$ & $0.274 \pm 0.138(27.4 \%)$ \\
\hline & 5 & $1(100 \%)$ & $0.283 \pm 0.269(28.3 \%)$ & $0.337 \pm 0.036(33.7 \%)$ & $0.380 \pm 0.002(38.0 \%)$ \\
\hline
\end{tabular}

the water soluble and insoluble water concentrations were increased by increased initial boron concentration. Under high boron concentrations, plant roots and leaves decomposed due to the toxic effect of boron. These results indicated that with increase in initial boron concentration, more soluble boron was converted to insoluble boron forms that were difficult to remove. Overall, accumulated boron was found to be major form of boron. The mass balance analyses of boron indicated that the main B removal mechanism of L. minor was firstly biosorption and then accumulation in plant tissues.

\subsection{Boron removal from geothermal water}

Experiments with real geothermal water were conducted using the previously found optimum operating conditions (initial pH: 8, water height: 1.5 $\mathrm{cm}$, and HA concentration: $0 \mathrm{mg} \mathrm{L}^{-1}$ ). Boron concentration followed a steady decreasing pattern from 10.48 to $4.24 \mathrm{mg} \mathrm{L}^{-1}$ through 7 days. When the $\mathrm{B}$ removal efficiencies were compared, there was a slight decrease from $65.2 \%\left(10 \mathrm{mg} \mathrm{L}^{-1}\right.$ B containing synthetic solution) to $59.5 \%$ (real geothermal water). The B content and bioconcentration factor were 1500 $\mathrm{mg} \mathrm{kg}^{-1}$ and 143.13 in geothermal water, respectively, as opposed to $1558 \mathrm{mg} \mathrm{kg}^{-1}$ and 155.8 in $10 \mathrm{mg} \mathrm{L}^{-1}$ boron containing synthetic solution. The slight decrease in removal efficiency and consequent decreases in B content and BCF were expected since real geothermal water was rich in ionic content. Moreover, a toxic response was not observed with the real geothermal water, which confirmed previous studies in the literature regarding salt tolerance of $L$. minor. [44] studied boron accumulation using L. minor under salt stress and they found that the growth rate and $\mathrm{B}$ absorption capacity were inhibited considerably at a $\mathrm{NaCl}$ concentration as high as $100 \mathrm{mM}$. It is known that the $\mathrm{B}$ biosorption is a passive transport process by mass flow across the plasmalemma of L. minor into the cell [45]. The high salt concentrations (45 mM) decrease the osmotic potential of aqueous solution, preventing transpiration and as a result, bisorption of B by plants is reduced [46]. Furthermore, the growth rate inhibition of the high salt concentrations on several species including, Spirodela polyrhiza, Lemna minor and Lemna gibba have been reported [47].

\section{Discussion and Conclusion}

This study aims at investigating the phytoremediation of boron rich waters using L. minor, a common duckweed. The results revealed that boron was absorbed in the first 2 days of experimental runs. However, at the end of the operating time of 2 days, the boron absorption capacity was constant due to the saturation level of plant. The results showed that the $B$ removal was significantly affected by the $B$ concentration, water height in cell, and initial HA concentration. Optimum $\mathrm{pH}$ value of aqueous solution was determined to be $\mathrm{pH} 8$, although no significant effect of pH change on boron removal was observed. However, the B content in synthetic solution increased with the increasing HA concentration due to the decomposition of L. minor.

The maximum boron removal efficiency for $5 \mathrm{mg} \mathrm{B} \mathrm{L}^{-1}$ was $96.7 \%$ (pH 8, water height of $1.5 \mathrm{~cm}$, without HA content). The boron removal efficiency decreased from $96.7 \%$ for $5 \mathrm{mg} \mathrm{B} \mathrm{L}^{-1}$ to $36.6 \%$ for $30 \mathrm{mg} \mathrm{B} \mathrm{L}^{-1} \mathrm{due}$ to the toxic effect of high boron content on Lemna minor. Visual assessments and ESEM analyses also showed B toxicity at high concentrations. Furthermore, the removal efficiency and B content of L. minor under optimum operating conditions was found to be $59.5 \%$ and $1500 \mathrm{mg} \mathrm{kg}^{-1}$ for real geothermal water.

Our results presented in this paper indicated that Lemna minor can be efficiently used for $\mathrm{B}$ removal from waters with low B concentrations. Hoagland solution is easy to access due to a plethora of suppliers in the agriculture sector. Its ready-to-mix powders that can prepare at least 200 liters of solution are sold for around 150 Turkish Liras (21 USD). Once used up, the $L$. minor can be screened out of the treatment ponds, dried at ambient temperature and then used for soil amendment at B-deficient areas if the water did not contain any toxic and potentially hazardous ions/compounds. Use of L. minor as fish feed at aquaculture facilities is another option. Therefore, $L$. minor can be used as an environmentally friendly and low-cost pre-treatment or post-treatment process for the treatment of aqueous solutions containing high boron concentrations. 


\section{Acknowledgement}

Authors would like to thank to Environmental Development Application and Research Center at IZTECH for boron analyses.

\section{Declaration of Ethical Code}

In this study, we undertake that all the rules required to be followed within the scope of the "Higher Education Institutions Scientific Research and Publication Ethics Directive" are complied with, and that none of the actions stated under the heading "Actions Against Scientific Research and Publication Ethics" are not carried out.

\section{References}

[1] WHO/UNICEF, 2014. Progress on Drinking-water and Sanitation-2014 Update. World Health Organization, 1, 1.

[2] Malley, Z. J. U., Taeb, M ., Matsumoto, T ., Takeya, H. 2009. Environmental sustainability and water availability: analyses of the scarcity and improvement opportunities in the Usangu plain, Tanzania, Phys. Chem. Earth, Parts A/B/C. 34, 313.

[3] Melikoğlu, M, 2017. Geothermal energy in Turkey and around the World: A review of the literature and an analysis based on Turkey's Vision 2023 energy targets, Renew. Sust. Energ. Rev. 76, 485492.

[3] Gallup, D . L. 2007. Treatment of geothermal waters for production of industrial, agricultural or drinking water, Geothermics. 36, 473-483.

[5] Baba, A., Sözbilir, H. 2012. Source of arsenic based on geological and hydrogeochemical properties of geothermal systems in Western Turkey, Chem. Geol., 334, 364-377.

[6] Kartikaningsih, D., Shih, Y. J ., Huang, Y. H . 2016. Boron removal from boric acid wastewater by electrocoagulation using aluminum as sacrificial anode, Sustain. Environ. Res. 1-6.

[7] Yılmaz, A. E., Boncukoğlu, R., Kocakerim, M. M., Yılmaz, M. T., Paluluoğlu, C. 2008 Boron removal from geothermal waters by electrocoagulation, J. Hazard. Mater., 153, 146-151.

[8] Barth, S., 2000. Utilization of boron as a critical parameter in water quality for thermal and mineral water resources in SW German and N Switzerland, Environ. Geol., 40, 1-2.

[9] Gude, V. G., 2016. Geothermal source potential for water desalination-current status and future perspective, Renew. Sust. Energ. Rev., 57, 10381065.

[10] Gemici Ü., Tarcan G. 2002. Distribution of boron in thermal waters of western Anatolia, Turkey, and examples of their environmental impacts, Environ. Geol., 1-8.

[11] Hilal, N., Kim, G. J., Somerfield, C. 2011. Boron removal from saline water: a comprehensive review, Desalination, 273, 23-35.

[12] Bryjak, M., Wolska, J., Kabay, N. 2008. Removal of boron from seawater by adsorption-membrane hybrid process: implementations and challenges, Desalination, 223, 57-62.

[13] Nielsen, F. H., 2002. The nutritional importance and pharmacological potential of boron for higher animals and human. In: Goldbach H.E., Brown P.H., Rerkasem B., Thellier M., Wimmer M.A., Bell R.W. (eds) Boron in Plant and Animal Nutrition. Springer, Boston, MA, 37s.

[14] WHO, 1998. Boron. Geneva, World Health Organization, International Programme on Chemical Safety.

[15] Banasiak, L. J., Schafer, A. I. 2009. Removal of organic trace contaminants by electrodialysis in a remote Australian community, Desalination, 248, 48-57.

[16] Ozbey-Unal, B., Imer, D. Y., Keskinler, B., Koyuncu, I. 2018. Boron removal from geothermal water by air gap membrane distillation, Desalination, 433, 141-150.

[17] Kabay, N., Köseoğlu, P., Yapıcı, D., Yüksel, Ü., Yüksel, M. 2013. Coupling ion exchange with ultrafiltration for boron removal from geothermal water-investigation of process parameters and recycle tests. Desalination, 316, 17-22.

[18] Yavuz, E., Arar, Ö., Yüksel, M., Yüksel, Ü., Kabay, N., 2013. Removal of boron from geothermal water by RO system-II-effect of $\mathrm{pH}$, Desalination, 310, 135-139.

[19] Nagaraj, R., Thirugnanamurthy, D., Rajput, M. M., Panigrahi, B. K. 2016. Techno-economic analysis of hybrid power system sizing applied to small desalination plants for sustainable operation, Int. J. Sustain. Built Environ., 5, 269-276.

[20] AlMarzooqi, F. A., Al Ghaferi-Saadat, I, Hilal, N. 2014. Application of Capacitive Deionization in Water Desalination: A Review, Desalination, 342, 3-15.

[21] Taştan, B. E., Duygu, E., Dönmez G. 2012. Boron bioremoval by a newly isolated Chlorella sp. and its stimulation by growth stimulators, Water Res. $46,167-175$.

[22] Böcük, H., Yakar, A., Türker, O. C. 2013. Assessment of Lemna gibba L. (duckweed) as a potential ecological indicator for contaminated aquatic ecosystem by boron mine effluent, Ecol. Indic., 29, 538-548. 
[23] Türker, O. C., Yakar, A., Gür, N. 2017. Bioaccumulation and toxicity assessment of irrigation water contaminated with boron (B) using duckweed (Lemna gibba L.) in a batch reactor system, J. Hazard. Mater., 324, 151-159.

[24] Tatar, Ş. Y., Öbek, E. 2014. Potential of Lemna gibba L. and Lemna minor L. for accumulation of Boron from secondary effluents, Ecol. Eng. 70, 332-336.

[25] Yaseen, D. A., Scholz, M. 2016. Shallow pond systems planted with Lemna minor treating azo dyes, Ecol. Eng. 94, 295-305.

[26] Movafeghi, A., Khataee, A. R., Torbati, S., Zarei, M., Salehi Lisar, S. Y. 2013. Bioremoval of c. i. basic red 46 as an azo dye from contaminated eater by Lemna minor L.: modeling of key factor by neural network, Environ Prog Sustain Energy, 32, 10821089.

[27] Ekperusi, O. A., Sikoki, F. D., Nwachukwu, O. E. 2019. Application of common duckweed (Lemna minor) in phytoremediation of chemicals in the environment: State and future perspective, Chemosphere, 223, 285-309.

[28] Hoagland, D. R., 1948. Lectures on the inorganic nutrition of plants, Chronica Botanica Comp, Waltham, 154, 624.

[29] Mclay, C. L. 1976. The effect of $\mathrm{pH}$ on the population growth of three species of duckweed: Spirodela oligorrhiza, Lemna minor and Wolffia arrhizal, Freshwater Biol., 6, 125-136.

[30] Marín, C. M. D. C., Oron, G. 2007. Boron removal by the duckweed Lemna gibba: a potential method for the remediation of boron-polluted waters, Water Res., 41, 4579-4584.

[31] Wildes, R. A., Neales, T. F. 1970. The adsorption of boron by disks of plant storage tissues, Aust. J. biol. Sci., 24, 873-84.

[32] Pitman, M. G. 1963. The determination of the salt relations of the cytoplasmic phase in cells of beetroot tissue, Aust. J. biol. Sci., 16, 647-68.

[33] Blevins, D. G., Lukaszewski, K. 1998. Boron in plant structure and function, Annu. Rev. Plant Physiol. Mol. Biol., 49, 491-500.

[34] Davis, S. M., Drake, K. D., Maier, K. J. 2002. Toxicity of boron to the duckweed Spirodella polyrrhiza, Chemosphere, 48, 615-620.
[35] Grievea, C. M., Possa, J. A., Grattanb, S. R., Suareza, D. L., Smith, T. E. 2010. The combined effects of salinity and excess boron on mineral ion relations in broccoli, Sci. Hortic., 125, 179-187.

[36] Reid, R. 2010. Can we really increase yields by making crop plants tolerant to boron toxicity? Plant Sci., 178, 9-11.

[37] Naghii, M. R., Samman, S. 1997. The effect of borononplasma testoterone and plasma lipid in rats, Nutr. Res., 17, 523-531.

[38] Frick, H. 1985. Boron tolerance and accumulation in the duckweed, Lemna minor, J. Plant Nutr. 8, 1123-1129.

[39] Leenheer, J. A. 2009. Systematic approaches to comprehensive analyses of natural organic matter, Ann. Environ. Sci., 3, 1-130.

[40] Tipping, E. 2002. Cation Binding by Humic Substances; Cambridge University Press: Cambridge, 434s.

[41] Goli, E., Hiemstra, T., Rahnemaie R. 2019. Interaction of boron with humic acid and natural organic matter: Experiments and modeling, Chem. Geol., 515, 20 June 2019, 1-8.

[42] Hasan, S. A., Fariduddin, Q., Ali, B., Hayat, S., Ahmad, A. 2009. Cadmium: toxicity and tolarence in plants, J. Environ. Biol., 30, 165-174.

[43] Socrates, G., 2004. Infrared and Raman Characteristic Group Frequencies, Third Edition, John Wiley \& Sons, England, 316s.

[44] Liu, C., Gu, W., Dai, Z., Li, J., Jiang, H., Zhang, Q. 2018. Boron accumulation by Lemna minor $\mathrm{L}$. under salt stress, Sci. Rep., 8, 8954.

[45] Smith, T. E., Grattan, S. R., Grieve, C. M., Poss, J. A.,Suarez, D. L. 2010. Salinity's influence on boron toxicity in broccoli: II. Impacts on boron uptake, uptake mechanisms and tissue ion relations, Agr. Water Manage., 97, 783-791.

[46] Yermiyahu, U., Ben-Gal, A., Keren, R., Reid, R. J. 2008. Combined effect of salinity and excess boron on plant growth and yield, Plant Soil., 304, 73-87.

[47] Sree, K. S., Adelmann, K., Garcia, C., Lam, E., Appenroth, K. J. 2015. Natural variance in salt tolerance and induction of starch accumulation in duckweeds, Planta., 241, 1395-1404. 


\section{Appendices}

Appendix A. The toxic effect of boron on Lemna minor: (a) raw L. minor, (b) $30 \mathrm{mg} / \mathrm{L}$ of B-exposed L. minor, (c) ESEM images of raw L. minor, (d) ESEM images of $30 \mathrm{mg} / \mathrm{L}$ of B-exposed L. minor.

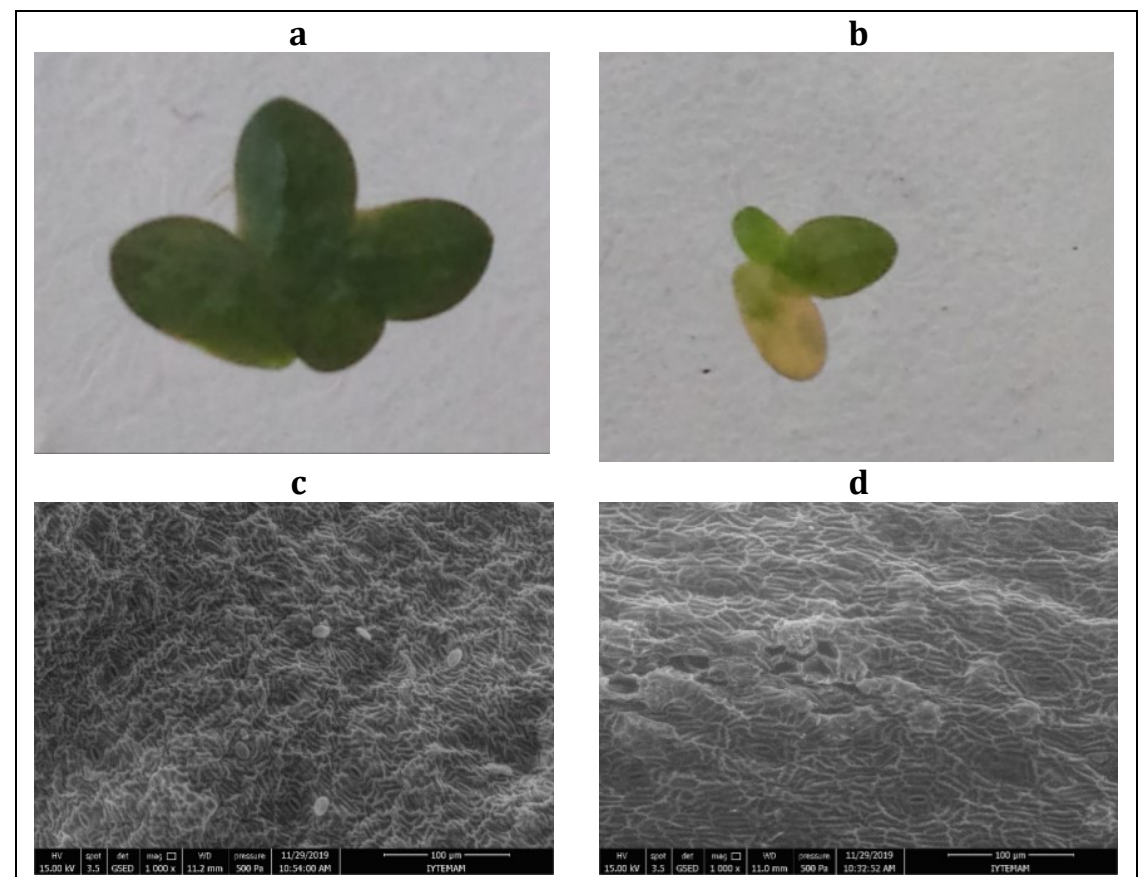


Appendix B. Elemental mapping results of raw and B-exposed L. minor samples $\left(20 \mathrm{mg} \mathrm{L}^{-1}\right.$ initial boron concentration, $\mathrm{pH} 8,1.5 \mathrm{~cm}$ water depth, $\left.0 \mathrm{mg} \mathrm{L}^{-1} \mathrm{HA}\right)$.

\begin{tabular}{|c|c|}
\hline Raw L. minor & Boron exposed $L$. minor \\
\hline $\mathrm{OK \alpha 1}$ & $\mathrm{O} \mathrm{K \alpha} 1$ \\
\hline Oxygen $\longdiv { 5 0 \mu m }$ & Oxygen \\
\hline \multirow[t]{2}{*}{ Carbon $\longdiv { 5 0 \mu m }$} & Carbon $\quad 100 \mu \mathrm{m}$ \\
\hline & Boron $\longdiv { 1 0 0 \mu m }$ \\
\hline
\end{tabular}


Appendix C. FTIR results of (a) B-exposed L. minor and (b) raw L. minor.

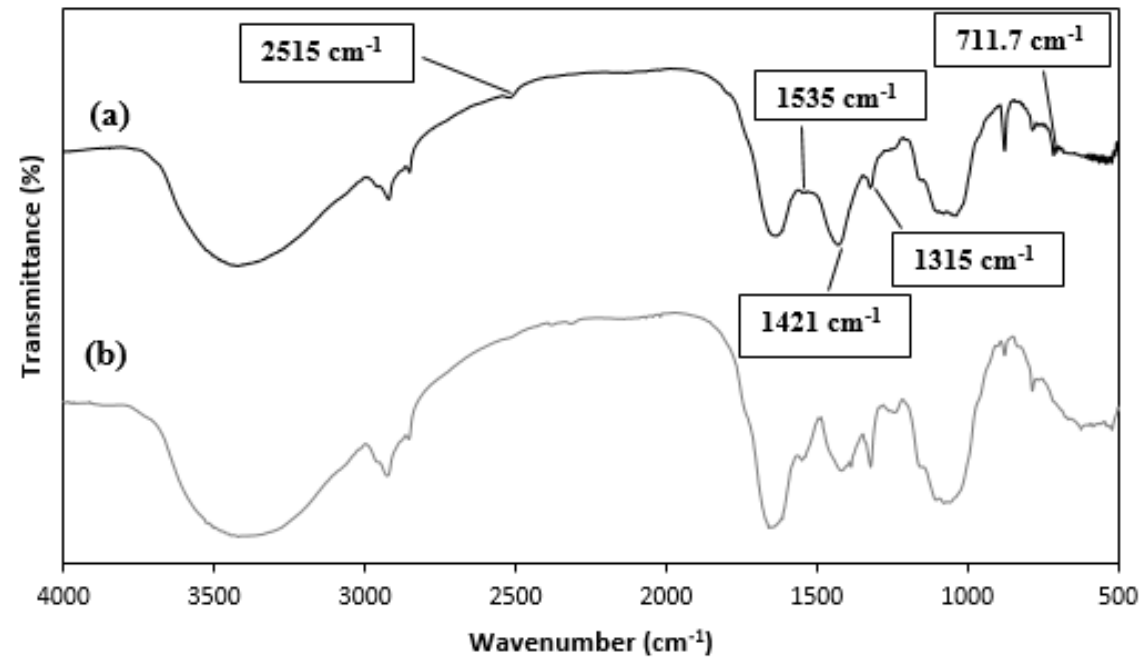

Appendix D. Elemental composition of raw and B-exposed L. minor samples.

\begin{tabular}{lcc}
\hline Element & Raw L. minor & B-exposed L. minor \\
\hline C (wt.\%) & 53.89 & 48.62 \\
O (wt.\%) & 42.51 & 41.62 \\
B (wt.\%) & N.D & 1.97 \\
Na (wt.\%) & 0.33 & 0.73 \\
Mg (wt.\%) & 0.42 & 0.72 \\
K (wt.\%) & 0.70 & 2.30 \\
Ca (wt.\%) & 2.15 & 4.04 \\
\hline
\end{tabular}

*N.D: not 